Original Article

\title{
BOTANICAL CHARACTERISTICS OF POLISH HONEYS FROM NATURA 2000 HABITATS
}

\author{
Anna Wróblewska* \\ Ernest Stawiarz \\ University of Life Sciences in Lublin, Department of Botany \\ Akademicka 15, 20-950 Lublin, Poland \\ *corresponding author: anna.wroblewska13@gmail.com \\ Received 11 July 2014; accepted 29 January 2015
}

\begin{abstract}
A b stract
Eighteen samples of honeys which were harvested over several beekeeping seasons from apiaries located in the area of the "Kózki" Nature Reserve (central-eastern Poland) were the subject of the present study. The "Kózki" Nature Reserve is included in the European Ecological Network Natura 2000 program. A microscopic analysis of the pollen sediment in the honeys showed the presence of 61 pollen types from 32 botanical families in the investigated material. There were represented by nectariferous (72.1\%) and nonnectariferous plants (27.9\%) and both entomophilous and anemophilous ones. The total number of pollen taxa in individual samples ranged from 13 to 37 . The main sources of nectar from trees and shrubs were: Frangula alnus, Prunus, Robinia pseudacacia, Rubus, Salix, Tilia. The main sources of nectar from herbaceous plants were: Anthriscus, Brassicaceae, Caryophyllaceae, Centaurea cyanus, Taraxacum, and Trifolium repens. Four unifloral honeys (three fruit tree honeys and one lime honey) and fourteen multifloral honeys, with a significant percentage of pollen from several nectariferous plant taxa, were distinguished in the studied material.
\end{abstract}

Keywords: botanical origin, honeys, Network Nature, Poland, pollen analysis.

\section{INTRODUCTION}

Microscopic pollen analysis is one of the methods that enable the botanical and geographical origin of bee products to be identified. The presence of pollen grains of various taxa in the sediment is also an important source of information concerning food resources for honey bees and other Apidae in the vicinity of an apiary. In Polish research articles on pollen analysis of bee products, honeys are the most frequent object of interest. The microscopic analysis of bee honeys in Poland was started in the second half of the last century by Demianowicz and Demianowicz (1955) as well as by Demianowicz (1961) who developed a method for harvesting unifloral honeys. The existing research on the pollen content in bee honeys was conducted in several regions of Poland by, inter alia, Lecewicz (1984) Warakomska (1996) Wróblewska et al. (2006) Wróblewska and Warakomska (2009) and Stawiarz and Wróblewska (2010, 2012).

The aims of the present study were to determine the taxonomic composition of pollen and based on pollen spectrum, to estahlish the nectar flora important for honey bees as well as to distinguish specific and multifloral honeys obtained in the area of the "Kózki" Nature Reserve covered by the Natura 2000 program. The reserve is located within the boundaries of the "Podlasie Bug Gorge" Landscape Park. The Bug River Valley is considered to be an ecological corridor of European importance. The protection of its ecological structure and biological diversity is of special significance for the entire European Union (Faliński et al., 2000; Landsberg, 2002). The study area is located in Masovia province which belongs to a group of regions which does not have a very high honeybee-colony density. The number of bee colonies per $1 \mathrm{~km}^{2}$ is 2.7 here, whereas the average all over is 4.2, and for all EU countries it is 3.2 (Semkiw, 2012). In 2012 and 2013, honey production in Masovia reached 1786.0 and 1672.9 tons, respectively, and was higher than the national average (Semkiw, 2012, 2013). The studied region is one of the least industrialised regions in Poland and therefore the flora in this area can offer nectar rewards of high ecological quality to insects. Honeys harvested from this area could obtain the so-called health food certificate. Among all the bee products 
honey is often used in biomonitoring of environmental contamination. Honey is often used to evaluate the biological characteristics of the area (Porrini et al., 2003; Bogdanov, 2006). It was Borowska (2011) who drew attention to the favorable environmental conditions for keeping ecological apiaries in Natura 2000 sites in Poland. Among 38 honeys registered in the national list of traditional products by the Ministry of Agriculture and Rural Development, 5 honeys are protected in the EU as a traditional regional product. In Europe, microscopic analysis of bee products from protected natural areas has been carried out in Spain (Terrab et al., 2003; Andrés et al., 2004; 2006), Portugal (Morais et al., 2011), and Lithuania (Čeksterytė et al., 2013).

\section{MATERIAL AND METHODS}

\section{Collection of honey samples}

Eighteen honey samples were collected for analysis over the period from 2008 to 2013 . They came from individual apiaries located in the area of the "Kózki" Nature Reserve $\left(52^{\circ} 21^{\prime} \cdot 42.54^{\prime \prime} \mathrm{N}\right.$. $\left.22^{\circ} 51^{\prime} 39.61 " \mathrm{E}\right)$, which is a protected area included in the European Ecological Network Natura 2000 (Fig. 1). This nature reserve, located in the Municipality of Sarnaki (Masovia province), occupies an area of 82.1 ha. Geographically, this reserve is situated in the province of the Central Polish Lowlands (Niziny Środkowopolskie), South Podlasie Lowland (Nizina Południowopodlaska) macroregion, and Siedlce Upland (Wysoczyzna Siedlecka) mezoregion (Kondracki, 2009). Various plant communities with many plant species, both herbaceous and woody, are found in the area of the reserve (Marciniuk, 2009; Warda et al., 2011; Wróblewska et al., 2012; Kulik et al., 2013). The characteristic landscape features include sandy grassland patches which occur frequently in the immediate vicinity of meadows and pastures as well as forest and thicket communities (Dombrowski and Wereszczyńska, 1991; Warda et al., 2011).

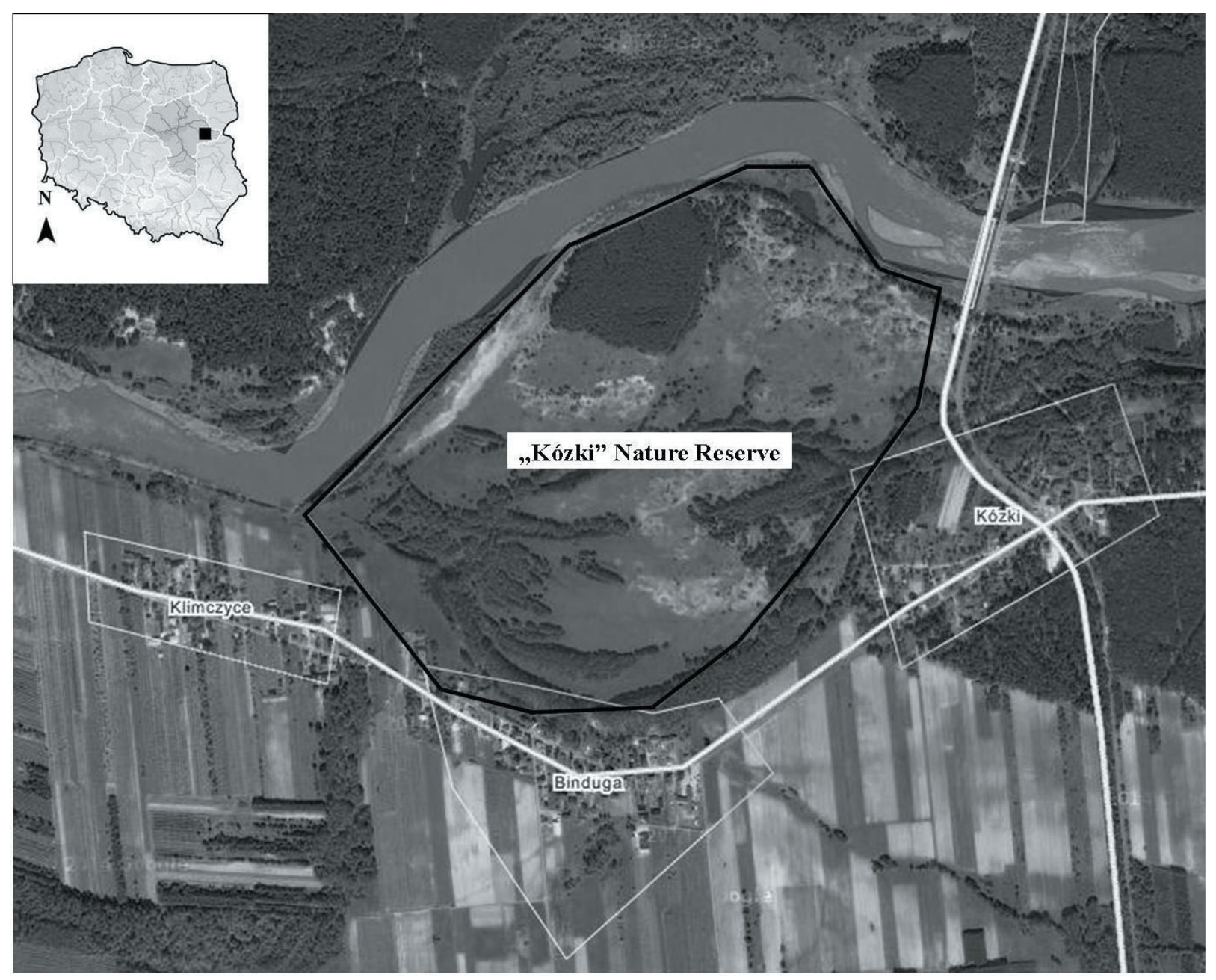

Fig. 1. Map of the study area. 


\section{Melissopalynological study}

The microscopic analysis of the honeys was performed following the recommendations of the International Commission for Bee Botany of IUSB (Louveaux et al., 1978), in accordance with the requirements of the International Honey Commission (IHC) (von der Ohe et al., 2004) and the guidelines of the Polish Standard "Bee Honey" (PN-88/A-77626, 1988). In each slide, at least 300 pollen grains were counted (Moar, 1985). Pollen grains were identified, if possible, to the level of species (e.g. Frangula alnus), type of structure (Prunus type), genus (Tilia), or family (Caryophyllaceae). In relation to the representatives of Brassicaceae and Poaceae, the term "other" (other Brassicaceae, other Poaceae) was additionally used. This term includes other pollen taxa from these families present in the honey sediment which were not identified to the genus or species level. During the identification process, pollen keys (Zander, 1935, 1937; Sawyer, 1988; Faegri and Iversen, 1993; Ricciardelli d'Albore, 1998) and reference slides were used. In the group of nectariferous pollen, the following classification of pollen percentages was used for each sample analysed: dominant pollen >45\%; secondary pollen 16 - 45\%; important minor pollen 3 - 16\%; minor pollen $<3 \%$. The nomenclature of pollen taxa followed the guidelines of Zander $(1935,1937)$. The pollen of particular taxa was assigned to specific botanical families. In individual microscopic slides, the percentage of pollen from nectariferous and nonnectariferous plants was determined. Based on the pollen analysis results, unifloral and multifloral honeys were distinguished in the investigated material. The honeys were classified on the basis of the pollen percentages of particular taxa in the group of nectariferous plants. As far as the unifloral honeys are concerned, in the case of most of them, the pollen of a nectariferous dominant taxon must reach a percentage of at least $45 \%$ (Zander, 1935, 1937; Warakomska, 1987; Polish Standard PN-88/A77626, 1988; Wróblewska, 2002). Due to the low contamination of lime nectar with its own pollen, unifloral lime honey should contain at least $20 \%$ of Tilia pollen. In the fruit tree honeys, the percentage of pollen grains of Prunus and Malus types was calculated together.

\section{RESULTS}

\section{Pollen spectrum}

Pollen grains of 61 taxa were found to be present in the sediments of the honey samples, among which nectariferous plants accounted for $73.8 \%$, while non-nectariferous plants, represented by the entomophilous and anemophilous species, made up $26.2 \%$ (Fig. 2 - 3). The presence of 13 - 37 pollen taxa in total, was found in individual samples. The pollen of 9 - 24 taxa originated from nectariferous plants, while the pollen of 2 - 13 taxa originated from non-nectariferous plants. The identified pollen grains belonged to 32 botanical families (Fig. 4). The following were represented in the greatest numbers: Asteraceae, Fabaceae and Rosaceae, and seven different pollen types were recorded within each of them (Fig. 4).

From among the 45 nectar-producing taxa from 23 botanical families, Frangula alnus, Prunus type, and Salix reached the highest frequency in the studied material; their pollen grains were present in all the honeys investigated. In this group, the following also showed a high frequency (more than 50\%): Brassicaceae (including Brassica napus), Centaurea cyanus, Rubus type, Trifolium repens, Anthriscus type, Robinia pseudacacia, Tilia, Taraxacum type, and Caryophyllaceae (Fig. 2). Non-nectar-producing plants were represented by 12 botanical families which included 16 pollen types, among which Filipendula and Poaceae showed a frequency of more than $50 \%$ (Fig. 3). The percentage of nectariferous pollen in the investigated honeys and the percentage of non-nectariferous taxa in individual samples are shown in Table 1 and in Figure 2.

\section{Nectariferous flora}

The microscopic analysis results revealed that the honey samples were characterised by rich and varied floral pollen assemblages. Most of the plant taxa $(73.8 \%)$ present in the honeys are a source of nectar food for bees. In the group of eleven recorded nectar-producing tree and shrub taxa, Prunus and Salix can be considered to be spring nectar sources in the study area. Frangula alnus, Robinia pseudacacia, Rubus, and Tilia, which bloom in late spring and early summer, provide similarly abundant nectar rewards.

Among the trees and shrubs, Prunus and Salix, which provide nectar and pollen during the early spring period when the food requirement of a bee colony is highest, can be considered to be the main sources of this raw material for honey. Frangula alnus, Robinia pseudacacia, and Tilia, which provide food to insects at the turn of spring and early summer, are also an abundant source of nectar. Rubus, commonly found in different regions of Poland, also offers good nectar rewards. Among the nectariferous taxa representing 


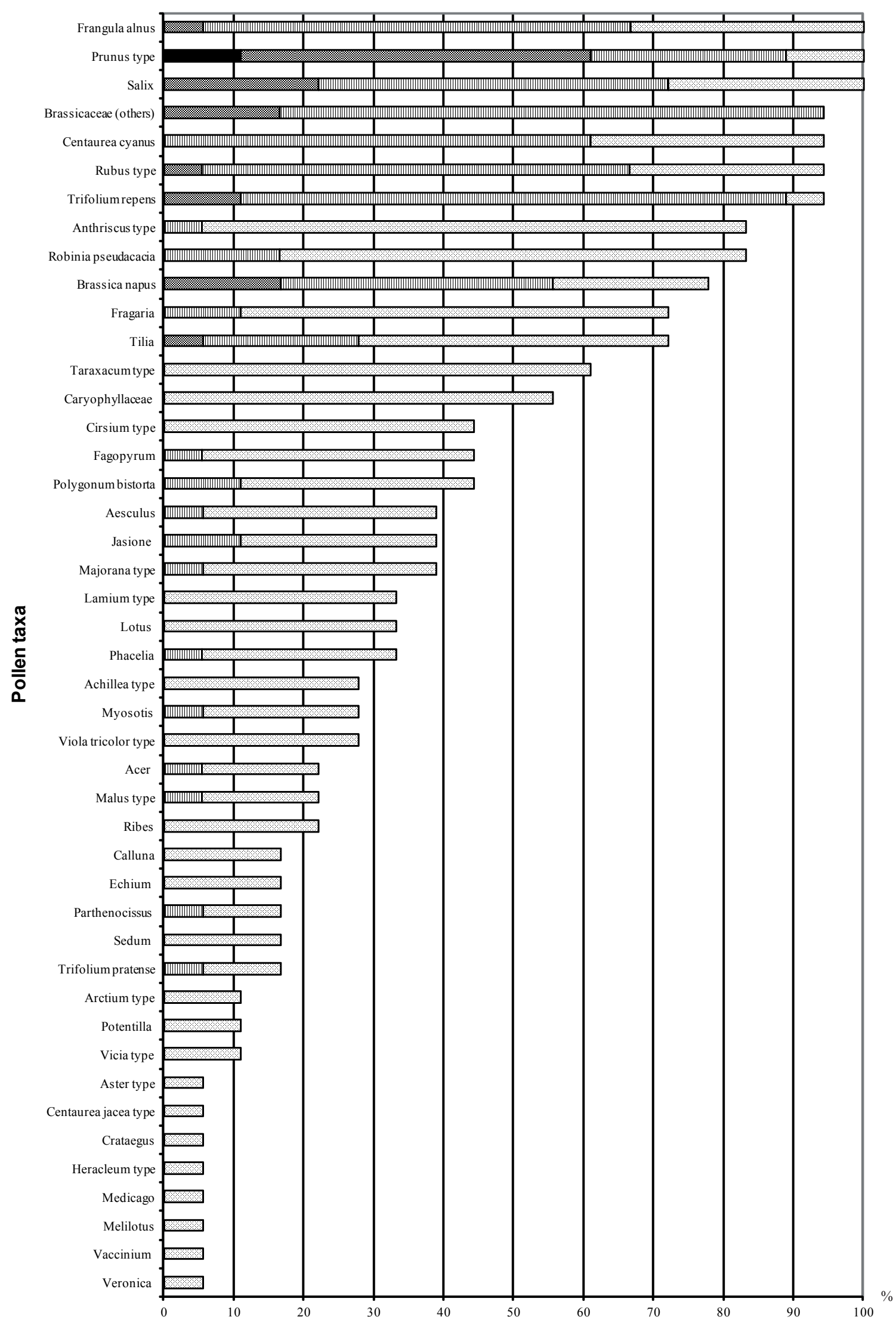

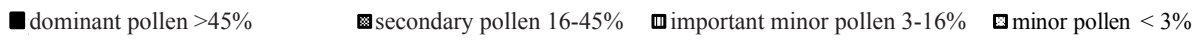

Fig. 2. Pollen frequency of nectariferous plants and its contribution in the microscopic image of the examined honeys (\%). 


\section{J. APIC. SCL. VOL. 59 NO. 12015}

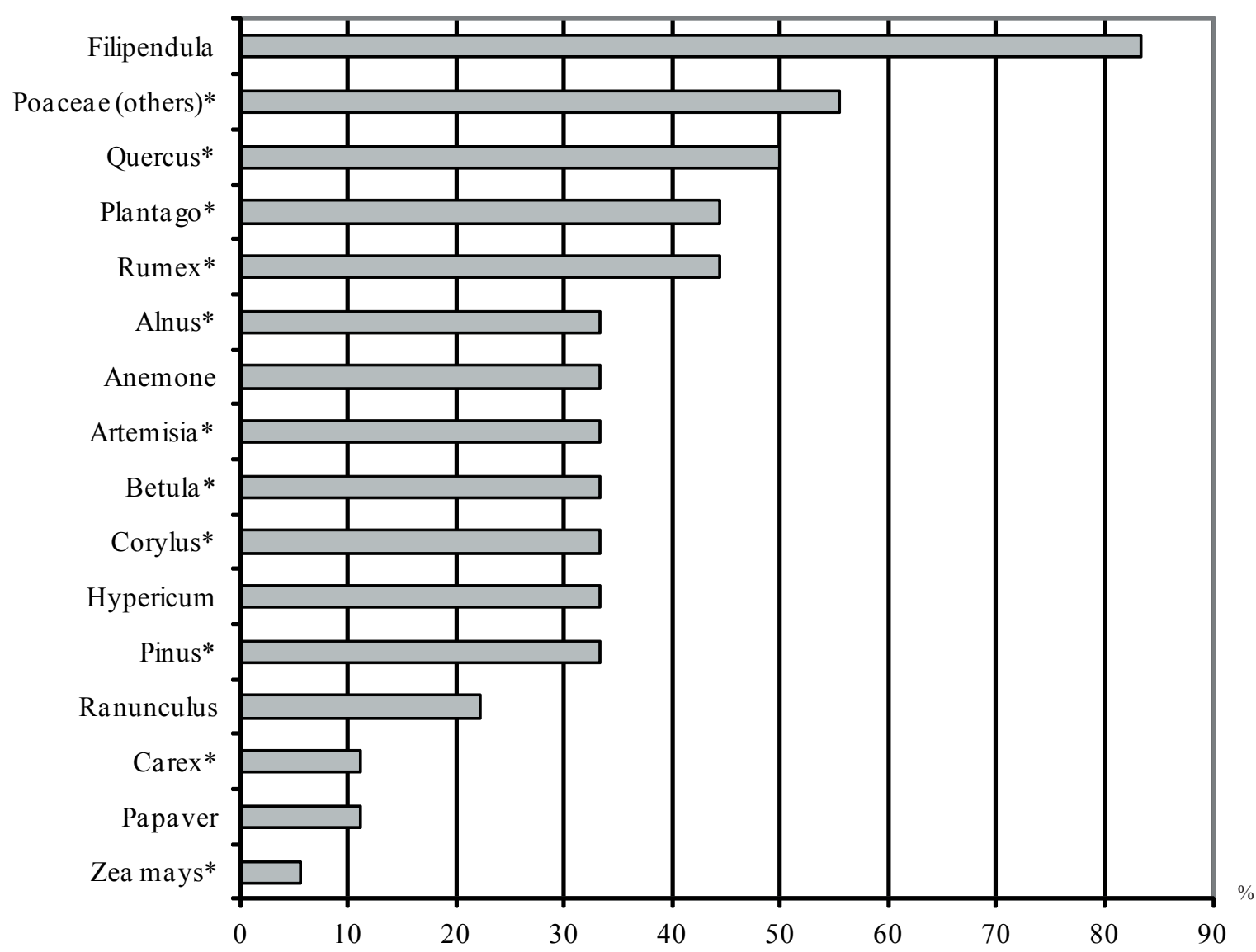

Fig. 3. Pollen frequency of non-nectariferous plants in the examined honeys (\%). * - anemophilous taxa

herbaceous plants, Brassicaceae (including Brassica napus), Trifolium repens, and Anthriscus, Centaurea cyanus, Caryophyllaceae, and Taraxacum, whose pollen reached a frequency ranging 55 - 95\%, belong to the most important taxa within the study агеa. Flowers of the above-mentioned plant taxa provide food to insects in spring and summer during the full flowering period. Among the other pollen grains recorded in the honeys, herbaceous taxa were by far the most predominant, but they reached a much lower frequency and lower pollen percentages in the investigated material (Fig. 2). Nevertheless, they supplement food sources for insects during various periods of the beekeeping season.

\section{Botanical classification of honeys}

Four unifloral honeys and fourteen multifloral honeys were distinguished. The group of unifloral honeys included three fruit tree honeys and one lime honey. Two fruit tree honeys were determined to be Prunus honeys. The percentage of Prunus type pollen reached in the two fruit tree honeys was $49.76 \%$ and $52.35 \%$, respectively. The third fruit tree honey was a mixed honey and the combined percentage of Prunus type and Malus type pollen was $53.44 \%$. In the lime honey, the percentage of Tilia pollen grains was $28.41 \%$ (Tab. 1). In the pollen spectrum of the other fourteen honeys identified as multifloral, from 20 to 37 pollen types were found to be present in individual samples. Nectariferous taxa accounted for 81.56 - 97.07\%. A significant proportion (25 - 45\%) of pollen from several taxa was found in this group of honeys. The pollen types were: Prunus type (in seven samples), Salix and Brassica napus (three), Trifolium repens (two), and Rubus type (one) (Tab. 1). The pollen percentages for more important nectariferous taxa and a fragment of the microscopic image of some of the honeys are included in the Table 1 and in Figure 5.

\section{DISCUSSION}

The microscopic analysis results showed a varying composition of floral pollen in the sediment of the honeys. Among the 61 pollen types recorded, nectariferous plants, which provide bees with the raw material for honey, accounted for $72.1 \%$. Frangula alnus, Prunus type, and Salix showed the highest frequency (100\%) in the group of nectariferous taxa. In Poland and other European countries, these taxa 


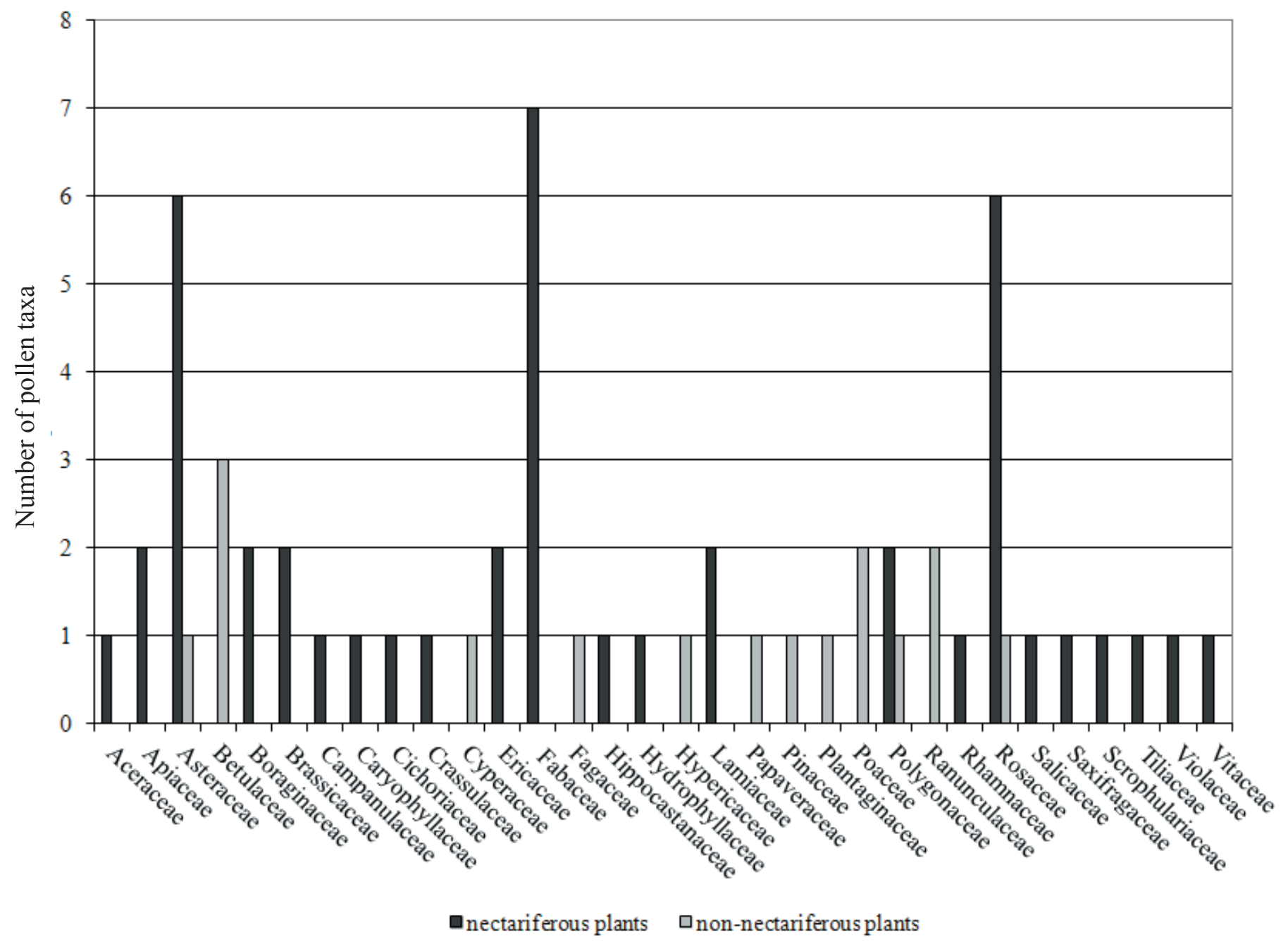

Fig. 4. Number of pollen taxa within the botanical families.
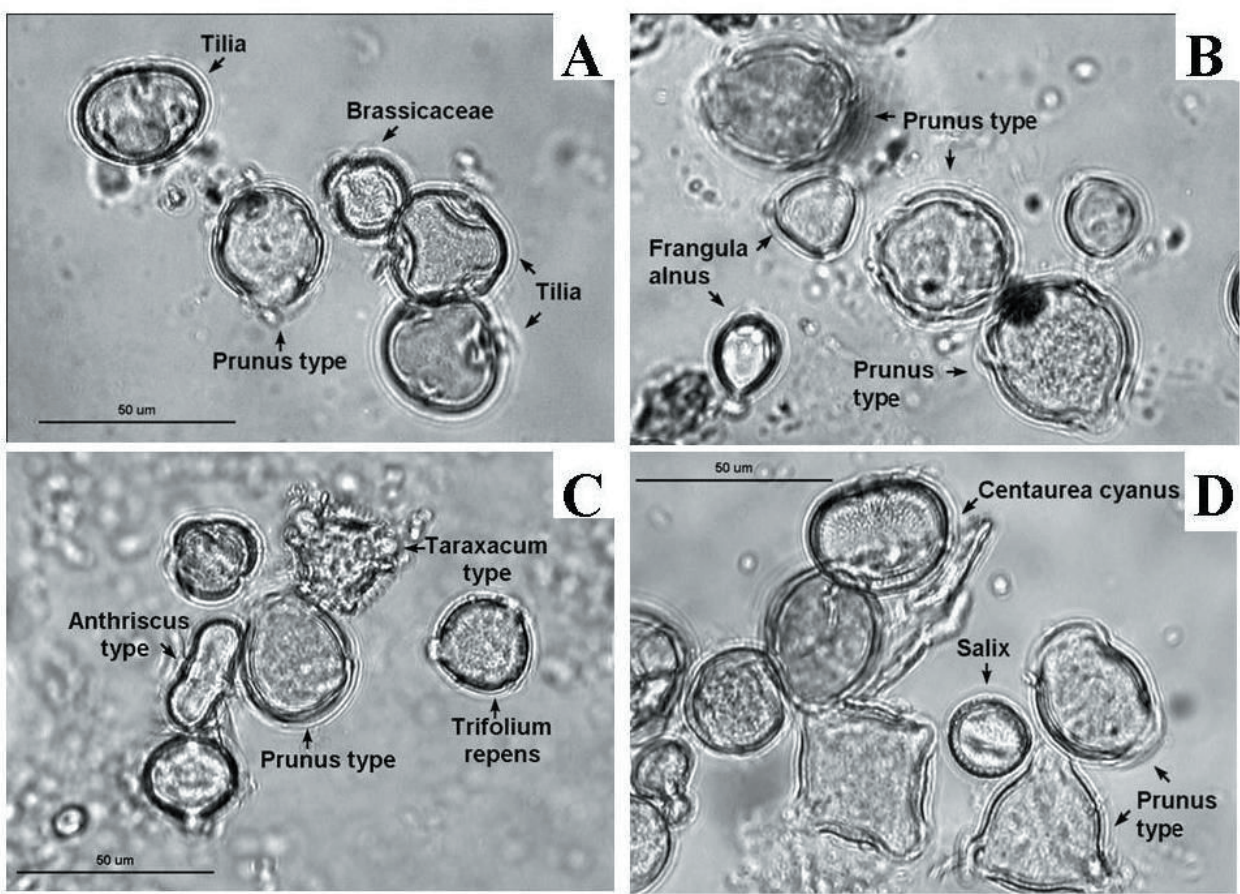

Fig. 5. A part of the microscopic image of selected honeys: A - lime (2/2011), B - fruit tree (4/2012), C - multifloral (1/2010), D - multifloral (1/2013). 


\section{J. APPC. SCL. VOL. 59 N NO. 12015}

produce abundant nectar when weather conditions were favorable and the high frequency and percentage of their pollen in honeys are confirmed in research articles (Warakomska, 1987; Persano Oddo et al., 2004; Stawiarz, 2006; Wróblewska et al., 2006; Salonen et al., 2009; Wróblewska and Warakomska, 2009; Sabo et al., 2011; Čeksterytė et al., 2013; Dobre et al., 2013). Brassicaceae, Centaurea cyanus, Rubus type, Trifolium repens, Anthriscus type, Robinia pseudacacia, Tilia, Taraxacum type, and Caryophyllaceae, with a pollen frequency of more than $50 \%$, are also attractive sources of pollen to insects. The other taxa recorded in the honeys are supplementary food resources for Apidae. Among the 32 botanical families, Asteraceae, Fabaceae, and Rosaceae were represented in the greatest numbers in the pollen spectrum. The abundance of the representatives of these families in the study area was confirmed by the observations of Marciniuk (2009). From ten botanical families, Marciniuk (2009) noted that the three above mentioned ones occur most abundantly in marginal habitats of the Podlasie Bug River Gorge (Podlaski Przełom Bugu). Flowers of many representatives of these families are readily visited by insects taking advantage of the nectar as reported by many authors in numerous publica-

Table 1.

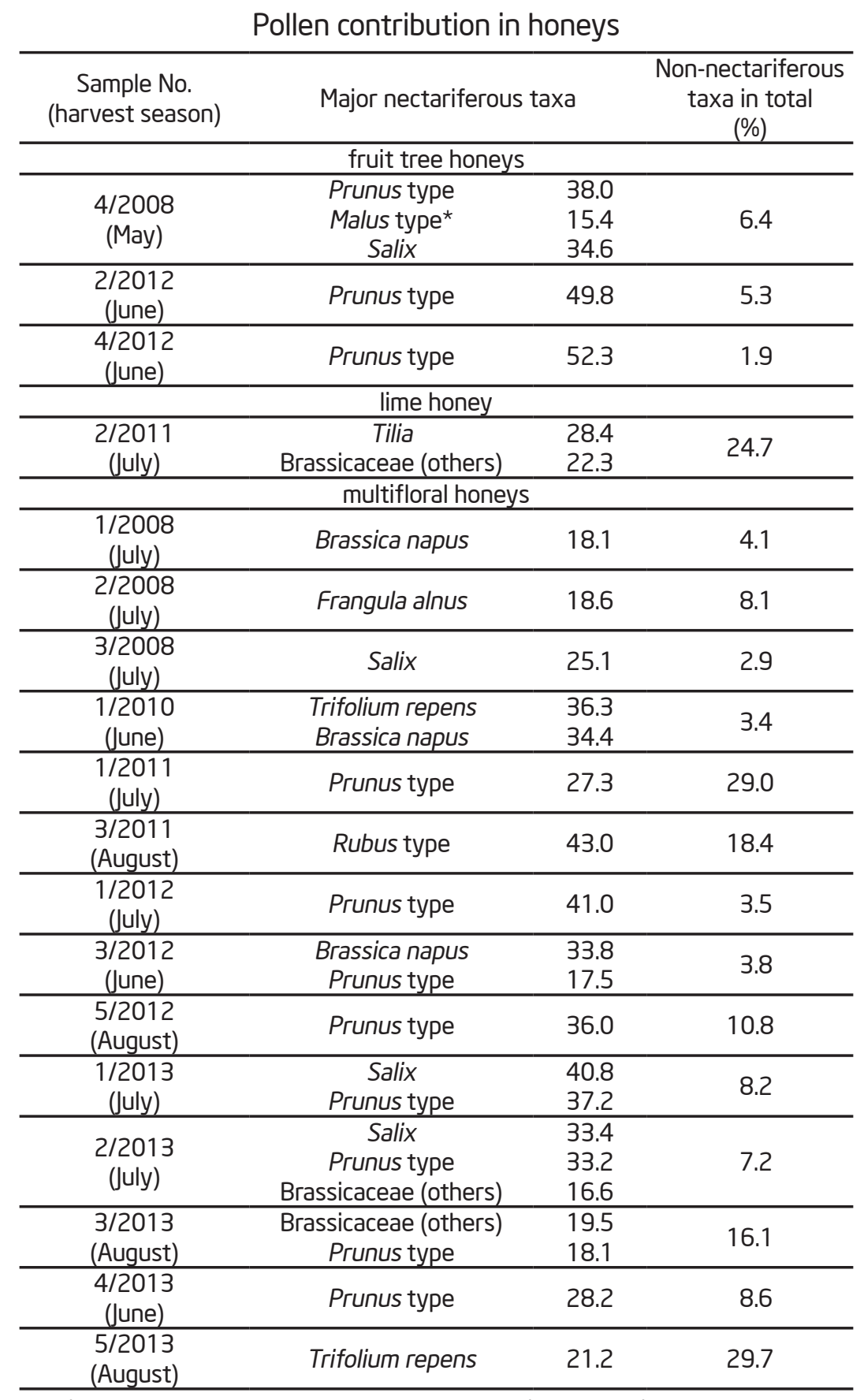

dominant pollen $>45 \%$, secondary pollen 16 - 45\%; important minor pollen 
tions evaluating the apicultural value of various plant species. The many authors include: Crane et al. (1984), Wróblewska et al. (1993), and Farkas and Zajácz (2007).

In the group of non-nectariferous plants, pollen grains of the entomophilous taxon Filipendula as well as of the anemophilous taxa Poaceae and Quercus were most frequenly found. The presence of these pollen grains is often recorded in the pollen spectrum of the honeybee honeys as an effect of secondary contamination (Warakomska, 1985; 1996; Wróblewska, 2002; Andrés et al., 2004; Stawiarz, 2006; 2009; Jerković et al., 2011; Dobre et al., 2013).

From among the eighteen samples, in the three fruit tree honeys, the Prunus type pollen grains were largely predominant, and reached a dominant proportion (>45\%) in two samples, while in one sample this pollen type was secondary (16 - 45\%). One sample of mixed honey from the Prunus and Malus source, was characterised by a total percentage of $53.44 \%$ for the pollen of both these taxa. In the studied material, Prunus type pollen grains reached a $100 \%$ frequency which was attributable to the abundant occurrence of trees and shrubs of the genus Prunus in the study area (Wróblewska et al., 2012). In the species composition of the dendroflora in the Kózki reserve, the family Rosaceae was represented in the greatest numbers. Within the Rosaceae family Prunus spinosa and Prunus avium were by far predominant. Single apple trees growing in the wild in this reserve can offer small Malus nectar rewards. In some European countries, under favorable weather conditions, bee keepers obtain honeys from fruit trees when the trees flower abundantly. Such honeys are harvested, among others, in Spain (Pérez-Arquillué et al., 1995; Persano Oddo et al., 2004), Croatia (Jerković et al., 2011), Lithuania (Čeksterytè et al., 2013), and Romania (Dobre et al., 2013) where various species of the genus Prunus are found in great numbers in the wild. In Poland, varietal honeys from fruit trees can only be obtained in some regions of the country, and only under favorable weather conditions for flowering and nectar production (Wróblewska, 2002; Wróblewska and Warakomska, 2009; Stawiarz and Wróblewska, 2012). Pollen from Prunus and Malus flowers is particularly valuable during the spring period when abundant food is necessary for the proper development of bee colonies.

The only lime honey in the investigated material contained $28.41 \%$ of Tilia pollen. From the genus Tilia, Tilia cordata was primarily recorded in the study area (Marciniuk, 2009). Due to the low contamination of lime nectar with its own pollen, in lime honeys the percentage of Tilia pollen in the group of nectariferous taxa should reach at least 20\% (Polish Standard PN-88/A-77626, 1988). The genus Tilia is represented by numerous species which in many European countries belong to major nectar-producing plants. These plants provide the raw material for the production of lime honeys (Persano Oddo and Piro, 2004; Persano Oddo et al., 2004). In Poland, lime honeys are harvested in different regions of the country (Warakomska, 1996; Wróblewska, 2002; Stawiarz, 2009; Wróblewska and Warakomska, 2009; Waś et al., 2011).

Microscopic analysis showed a much higher variation in the pollen assemblage in the multifloral honeys compared to the unifloral honeys. The number of pollen taxa in individual samples of the multifloral honeys ranged from 20 to 37, while in the unifloral honeys this range was from 9 to 18 . In the multifloral honeys, 7 taxa were found in the secondary pollen group (16 - 45\%). The Prunus type was found to be present in eight samples of these honeys, and this type was represented in the greatest numbers. Among the herbaceous plants, Brassicaceae and Trifolium repens, were present in the great numbers in the study area, and these plants provided large pollen rewards. The Brassicaceae and Trifolium repens pollen grains were secondary pollen in several honeys. Brassica napus nectar rewards probably originated from oilseed rape crops adjacent to the nature reserve.

Multifloral honeys are some of the most frequently harvested honeys in many European countries. In Poland, multifloral honeys have been the subject of research by among others, Warakomska (1996), Wróblewska et al., (2006), Wróblewska and Warakomska (2009), Stawiarz and Wróblewska (2010).

\section{CONCLUSIONS}

The results of the melissopalynological analysis of honeys showed that the area of "Kózki" Nature Reserve included in the European Ecological Network Natura 2000 was characterised by a diversity of flora which provides ecological food sources for honey bees for several months of the growing season. The most important nectariferous plant among the trees and shrubs were: Frangula alnus, Prunus, Robinia pseudacacia, Rubus, Salix and Tilia. The most important nectariferous plants among herbaceous taxa were: Anthriscus, Brassicaceae, Caryophyllaceae, Centaurea cyanus, Taraxacum and Trifolium repens. 
In the study region, multifloral honeys were the most frequently harvested. In the examined material among the unifloral honeys there were: three fruit trees honeys from Prunus and Malus, and one lime honey from Tilia.

Environmental conditions on the Natura 2000 area are favorable for obtaining ecological honeys. The presence of honey bees as plant pollinators may contribute to the conservation of biodiversity in the Natura 2000 area.

\section{ACKNOWLEDGMENTS}

This research was supported financially by the Ministry of Science and Higher Education of Poland (project nr N N305 411038).

\section{REFERENCES}

Andrés C., Díez M. J., Terrab A. (2004) Análisis polínico de mieles de los Parques Naturales Sierra Norte de Sevilla y Sierras Subbéticas. Lazaroa 25: 125-133.

Andrés C., Díez M. J., Terrab A. (2006) Análisis polínico de mieles en de los Parques Naturale el Parque Natural de Donana. Polen 15: 45-53.

Bogdanov S. (2006) Contaminants of bee products. Apidologie 37: 1-18. DOl: 10.1051/apido:2005043

Borowska A. (201 1). Stan i perspektywy rozwoju pszczelarstwa w Polsce ze szczególnym uwzględnieniem miodów regionalnych. Zeszyty Naukowe ScGW w Warszawie - Problemy Rolnictwa Światowego 11 (26): 37-47.

Čeksterytè V., Kurtinaitienè B., Balžekas J. (2013) Pollen diversity in honey collected from Lithuania's protected landscape areas. Palynology 62(4): 277-282. DOl: 10.3176/proc.2013.4.08

Crane E., Walker P., Day R. (1 984) Directory of important world honey sources. International Bee Research Association. London. 384 pp.

Demianowicz Z. (1961) Pollenkoeffizienten als Grundlage der quantitative Pollenanalyse des Honigs. Pszczelnicze Zeszyty Naukowe 5(2): 95-105.

Demianowicz A., Demianowicz Z. (1955) Nowe podstawy analizy pyłkowej miodów. Pszczelnicze Zeszyty Naukowe 1: 185-195.
Dobre I., Alexe P., Escuredo O., Seijo C. M. (2013) Palynological evaluation of selected honeys from Romania. Grana 52(2): 113-121. DOl: 10.1080/00173134.2012.724443

Dombrowski A., Wereszczyńska A. (1991) Dokumentacja przyrodnicza rezerwatu faunistyczno-florystycznego Kózki. Urząd Wojewódzki w Białej Podlaskiej. Siedlce. $13 \mathrm{pp}$.

Faegri K., Iversen J. (1993) Bestimmungsschlüssel für die nordwesteuropäische Pollenflora. Gustav Fischer Verlag Jena. Stuttgard - New York. 85 pp.

Faliński J. B., Ćwikliński E., Głowacki Z. (2000) Atlas geobotaniczny doliny Bugu. Białowieska Stacja Geobotaniczna Uniwersytetu Warszawskiego. Warszawa. 320 pp.

Farkas Á., Zajácz E. (2007) Nectar production for the Hungarian honey industry. Global Science Books. The European Journal of Plant Science and Biotechnology 1(2): 125-151.

Jerković I., Marijanović Z., Staver M. M. (2011) Screening of natural organic volatiles from Prunus mahaleb L. honey: coumarin and vomifolial as nonspecific biomarkers. Molecules 16(3): 2507-2518. DOl: 10.3390/molecules 16032507

Kondracki J. (2009) Geografia regionalna Polski. PWN. Warszawa. 441 pp.

Kulik M., Warda M., Leśniewska P. (2013) Monitoring the diversity of psammophilous grassland communities in the Kózki Nature Reserve under grazing and non grazing conditions. Journal of Water and Land Development 19: 59-67. DOl: 10.2478/jwld-2013-0017

Landsberg M. (Ed.) (2002) Bug: identification and review of water management issues. Report No 2. Working Group on Monitoring and Assessment under the UNECE Water Convention. Warszawa - Lublin. 160 pp.

Lecewicz W. (1984) Miody odmianowe najczęściej występujące w południowej części Lubelszczyzny. Pszczelnicze Zeszyty Naukowe 25: 155-168.

Louveaux J., Maurizio A., Vorwohl G. (1978) Methods of Melissopalynology. Bee World 59(4): 139-157.

Marciniuk P. (2009) Szata roślinna śródpolnych siedlisk Podlaskiego Przełomu Bugu. Instytut Botaniki im. W. Szafera. Polska Akademia Nauk. Kraków. 135 pp. 
Moar N. T. (1985) Pollen analysis of New Zealand honey. New Zealand Journal of Agricultural Research 28: 39-70.

Morais M., Moreira L., Feás X., Estevinho L. M. (2011) Hoeneybee collected pollen from five Portuguese Natural Parks: Palynological origin, phenolic content, antioxidant properties and antimicrobial activity. Food and Chemical Toxicology 49(5): 1096-1 101. DOl: 10.1016/j. fct.2011.01.020

Pérez-Arquillué C., Conchello P., Ariño A., Juan T., Herrera A. (1995) Physicochemical attributes and pollen spectrum of some unifloral Spanish honeys. Food Chemistry 54(2): 167-172. DOl: 10.1016/0308-8146(95)00022-B

Persano Oddo L., Piro R. (2004) Main European unifloral honeys: descriptive sheets. Apidologie 35(1): 38-81. DOI: 10.1051/apido:2004049

Persano Oddo S. L., Piana L., Bogdanov S., Bentabol A., Gotsiou P., Kerkvliet J., Martin P., Morlot M., Ortiz Valbuena A., Ruoff K., von der Ohe K. (2004) Botanical species giving unifloral honey in Europe. Apidologie 35(1): 82-93. DOl: 10.1051/apido:2004045

PN-88/A-77626 (1988) „Miód Pszczeli”. Dziennik Norm i Miar пr 8/1988, poz. 19. Wydawnictwo Normalizacyjne Alfa. Warszawa.

Porrini C., Sabatini A. G., Girotti S., Ghini S., Mędrzycki P." Grillenzoni F., Bortolotti L., Gattavecchia E., Celli G. (2003) Honey bees and bee products as monitors of the environmental contamination. Apiacta 38: 63-70.

Ricciardelli d'Albore G. C. (1998) Mediterranean melissopalynology. Università degli studi di Perugia, Facoltà di agraria, Istituto di entomologia agraria. Perugia. 466 pp.

Sabo M., Potočnjak M., Banjari l., Petrovič D. (201 1) Pollen analysis of honeys from Varaždin County, Croatia. Turkish Journal of Botany 35: 581 -587. DOl:10.3906/bot-100986

Salonen A., Ollikka T., Grönlund E., Ruottinen L., JulkunenTittoR.(2009)Pollenanalysis of honey fromFinland.Grana 48(4): 281-289. DOl: 10.1080/00173130903363550

Sawyer R. (1 988) Honey identification. Cardiff Academic Press. Wales, Great Britain. 115 pp.

Semkiw P. (2012) Sektor pszczelarski w Polsce w 2012 roku. Instytut Ogrodnictwa, Oddział Pszczelnictwa. Puławy. 17 pp. Available at: http://www.inhort.pl/files/program_wieloletni/wykaz publikacji/obszar3/Sektor\%20pszczelarski\%20w\%20 Polsce\%20w\%202012\%20roku.pdf

Semkiw P. (2013) Sektor pszczelarski w Polsce w 2013 roku. Instytut Ogrodnictwa, Oddział Pszczelnictwa. Puławy. 13 pp. Available at: http://www.inhort.pl/files/program_wieloletni/wykaz_ publikacji/obszar3/3.3_2013_1_Opracowanie.pdf

Stawiarz E. (2006) Spektrum pyłkowe miodów gminy Lipnik (woj. świętokrzyskie). Acta Agrobotanica 59(1): 251-256. DOl: 10.5586/aa.2006.025

Stawiarz E. (2009) Pollen of non-nectarious plants in the microscopic image of honeys of some communes of the Świętokrzyskie Voivodeship. Acta Agrobotanica 62(2): 53-58. DOl: 10.5586/aa.2009.026

Stawiarz E., Wróblewska A. (2010) Melissopalynological analysis of multifloral honeys from the Sandomierska Upland area of Poland. Journal of Apicultural Science 54(1):65-75.

Stawiarz E., Wróblewska A. (2012) Some monofloral honeys from the Sandomierz Upland. Allergology and Immunolgy 9(2-3): 161.

Terrab A., Andres C., Diez M. J. (2003) Análysis polínico de mieles de los Parques Naturales de Los Alcornocales y Sierra de Grazalema. Acta Botanica Malacitana 28: 79-87.

von der Ohe W., Persano Oddo L., Piana L., Morlot M., Martin P. (2004) Harmonised methods of melissopalynology. Apidologie 35(1): 18-25. DOl: 10.1051/apido:2004050

Warakomska Z. (1985) Obraz pyłkowy miodów i pierzgi Kotliny Jeleniogórskiej. Pszczelnicze Zeszyty Naukowe 29: 253-263.

Warakomska Z. (1 987) Miód, obnóża i pierzga z pożytku wierzbowego (Salix L.). Pszczelnicze Zeszyty Naukowe 31: 177-187.

Warakomska Z. (1996) Pollen contents of some honeys originating from Wielkoposka Region. Pszczelnicze Zeszyty Naukowe 40(2): 89-98.

Warda M., Kulik M. A., Gruszecki T. (2011) Charakterystyka wybranych zbiorowisk trawiastych w rezerwacie przyrody "Kózki” oraz próba ich czynnej ochrony przez wypas owiec rasy świniarka. Annales UMCS, Sec. E 66(4): 1-8. 
Waś E., Rybak-Chmielewska H., Szczęsna T., Kachaniuk K., Teper D. (201 1) Characteristics of Polish unifloral honeys. II Lime honey (Tilia spp.). Journal of Apicultural Science 55(1): 121-129.

Wróblewska A. (2002) Rośliny pożytkowe Podlasia w świetle analizy pyłkowej produktów pszczelich. Wydawnictwo Akademii Rolniczej w Lublinie. Lublin. 83 pp.

Wróblewska A., Warakomska Z. (2009) Pollen analysis of honeys from Poland's Lubelszczyzna regions. Journal of Apicultural Science 53(2): 57-67.

Wróblewska A., Ayers G. S., Hoopingarner R. A. (1993) Nectar production dynamics and bee reward: A comparison between Chapman's honey plant (Echinops sphaerocephalus L.) and blue globe thistle (Echinops ritro L.). American Bee Journal 133(1 1): 789-796.
Wróblewska A., Stawiarz E., Gruszecki T. (2012) Dendroflora Rezerwatu Przyrody „Kózki” w warunkach wypasu owiec oraz jej znaczenie jako źródła pożytku dla owadów. In: Gruszecki T. M. (Ed.) Czynna ochrona wybranych siedlisk Natura 2000 z wykorzystaniem rodzimych ras owiec. Uniwersytet Przyrodniczy w Lublinie. Lublin: 44-53.

Wróblewska A., Warakomska Z., Koter M. (2006) Pollen analysis of bee products from the North-Eastern Poland. Journal of Apicultural Science 50(1): 71-83.

Zander E. $(1935,1937)$ Beiträge zur Herkunftsbestimmung bei Honig. I Reichsfachgruppe Imker, Berlin. II. Liedloff. Loth \& Michaelis. Leipzig. 465 pp. 